\title{
DREAMS AND SEXUALITY
}

\section{A Psychoanalytical Reading of Klimt's Beethoven Frieze}

BENJAMIN FLYTHE

THIS ESSAY PRESENTS A PHILOSOPHICAL AND PSYCHOANALYTICAL INTERPRETATION OF THE WORK OF THE VIENNESE SECESSION ARTIST, GUSTAV KLIMT. THE MANNER OF DEPICTION IN KLIMT'S PAINTINGS UNDERWENT A RADICAL SHIFT AROUND THE TURN OF THE TWENTIETH CENTURY, AND THE AUTHOR ATTEMPTS TO UNVEIL THE INTERNAL AND EXTERNAL MOTIVATIONS THAT MAY HAVE PROMPTED AND CONTRIBUTED TO THIS TRANSFORMATION. DRAWING FROM FRIEDRICH NIETZSCHE'S THE BIRTH OF TRAGEDY AS WELL AS SIGMUND FREUD'S THE INTERPRETATION OF DREAMS, THE ARTICLE LINKS KLIMT'S EARLY WORK WITH WHAT MAY BE REFERRED TO AS THE APOLLONIAN OR CONSCIOUSNESS, AND HIS LATER WORK WITH THE DIONYSIAN OR THE SUBCONSCIOUS. IT IS THEN ARGUED THAT THE BEETHOVEN FRIEZE OF 1902 COULD BE UNDERSTOOD AS A "SELF-PORTRAIT" OF THE ARTIST AND USED TO EXAMINE THE SHIFT IN STYLISTIC REPRESENTATION IN KLIMT'S OEUVRE. 
Proud Athena, armed and ready for battle with her aegis and spear, cuts a striking image for the poster announcing the inaugural exhibition of the Vienna Secession. As the goddess of wisdom, the polis, and the arts, she is a decidedly appropriate figurehead for an upstart group of diverse artists who succeeded in fighting back against the established institution of Vienna, a political coup if there ever was one. Coupled with the motif of Theseus' slaying of the Minotaur in order to end the slaughter of Athenian children, this reading could not be more appropriate. The man responsible for both the poster design and for leading the revolutionary charge was Gustav Klimt, a man who in his youth worked within the system he would eventually help to dismantle. We know little about Klimt's personal life, and what we do know comes to us via the secondhand accounts of those that he worked and interacted with. We must then ask why Klimt underwent such a radical shift in style between his youth and maturity, and what were the factors, both internal and external, that may have prompted such a shift?

Perhaps an appropriate place to begin with is the goddess Athena and her own evolution through Klimt's art. Klimt was obviously fascinated with her, having painted her on at least three occasions: as a decoration in the spandrels of the Kunsthistorisches Museum stairwell (I890-9I), the poster previously mentioned (I897) and finally in a painting dedicated solely to the goddess, Klimt's Pallas Athena (I898). In the first piece, which was part of a series of spandrels that Klimt designed and executed for the Viennese art history museum, Athena is classically beautiful, naturalistically rendered as a stoic figure gazing coolly out from her lofty perch. She holds a winged Nike figure, symbolic of victory, perhaps referring to the triumphs of classical Greek art and architecture of which Athena is the patroness. But she is, for lack of a better term, boring - she is only a symbol, a reflection of herself, hardly even a shadow of the complex virgin-warrior-goddess of antiquity. Even the Athena in the poster for the first Secession exhibition is, despite the battle-ready nature of her appearance, somewhat restrained. But perhaps this is simply a result of the flattening of her form to its constituent lines which, as Carl Schorske explains, is "Klimt's new-found way of stating an abstraction. She sponsors a dramatic idea. Since it is not yet realized, it is treated as disembodied, allegorical, on the stage." We will explore this new means of representation at length later, and for the moment it will suffice to say that this is one of the first iterations of a theme in Klimt's work that will help us navigate the undeniable rift between his earlier and later works.
Pallas Athena (below), standing in stark contrast to both of these previous versions, takes their best characteristics and bridges the gap between them: she is softly modeled but still retains some of the poster's two-dimensionality ("a concept, not a concrete realization" ${ }^{2}$ ); the light in her eyes speaks to an internal fire that more accurately represents the truth of the goddess; and perhaps most importantly, the Nike she once supported has been replaced with a fully developed Nuda Veritas (as in Klimt's earlier illustration of the same figure for the Secessionist publication, Ver Sacrum). This tiny figure does not hold up a laurel wreath as her predecessor may have, but rather a mirror into which modern man may gaze introspectively. This pair of figures who turned their classical associations on their head and who established new associations are significant in that they fully embody the zeitgeist of the Secession: "Der Zeit ihre Kunst. Der Kunst ihre Freiheit [To the age, its art. To art, its freedom]." In the evolution of Athena from the cold, aloof icon to the impassioned, warrior goddess, we may begin to see a microcosm of Klimt's personal evolution. Athena served not only as the avatar for the Secessionists and their mission, but also in the same role for Klimt.

Friedrich Nietzsche, in his work The Birth of Tragedy, establishes a dichotomy which seems particularly appropriate in the present discussion: that which exists between the Apollonian and the Dionysiac. Apollo, the god of the

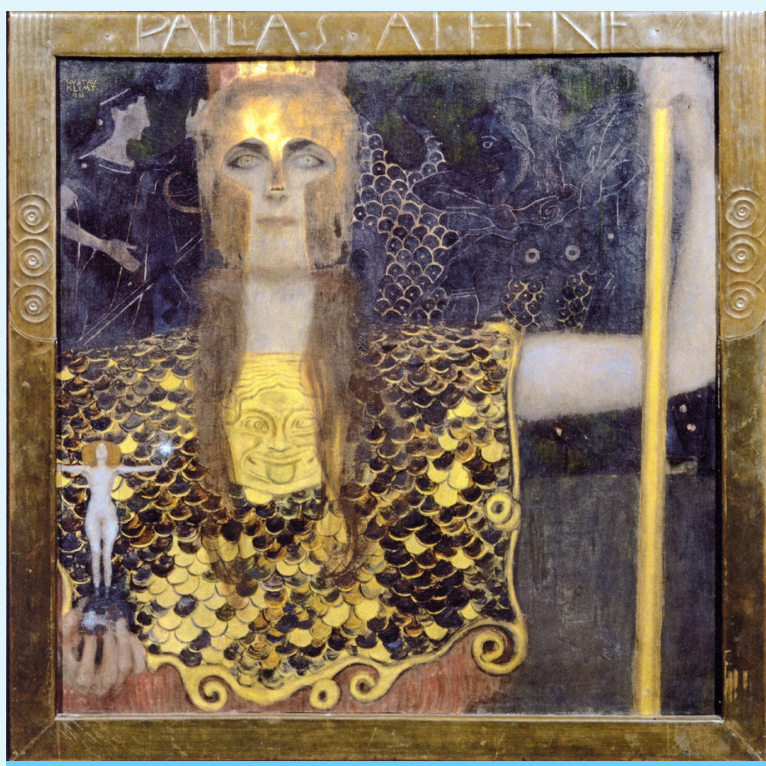

PALLAS ATHENA, 1898 BY GUSTAV KLIMT (COURTESY OF WIKIMEDIA COMMONS) 
plastic arts, of order, and of the illusionism inherent in much of Western art, is diametrically opposed to the other god of art, Dionysus, whose unbounded and primal music speaks to chaos and a state most likened to human intoxication. Klimt's early work, such as the Kunsthistorisches Athena and other decorative works for the Ringstrasse developments, was historicizing in appearance, suitable for the Viennese society that commissioned it. After all, this was the same government that erected, in the program of the Ringstrasse itself, a veritable monument to disparate historical periods, the design of each building hand-selected to best express the function of the institutions housed within. The extent to which Vienna attempted to maintain the illusion of historicism and rationality in design can be seen as Apollonian. Klimt, working in tandem with them, would have had the same associations.

However, as we know, this would change radically at the end of the nineteenth century. Klimt would begin to break down those very illusions that sustained the Viennese conception of reality and allow the sentiment of the Dionysiac - not necessarily through its associations to music, but rather the suggestion of something intensely personal and subjective-to seep into and diffuse throughout the work of the modern period. There are hints of this trend before I900: in particular, his Music panel in 1898 that decorated the music salon of Nikolaus Dumba. The abstract, geometric patterning of the background acts as a physical representation of the wholly intangible art of music, wild and untamable, but there is perhaps no better example in his early work than the controversy that surrounded the production of his three University panels, paintings that were to illustrate the disciplines of Philosophy, Medicine, and Jurisprudence. It is at this point that Klimt seems to undergo, as Schorske remarks, something of a "crisis of the liberal ego" 3 that also functions as the effective rift between not only his early and later work, but also between his periods of Apollonian and Dionysiac work.

Looking first to the Philosophy panel (right), this crisis becomes painfully obvious. Far from the "Victory of Light over Darkness" originally desired by the faculty of the University of Vienna, Klimt's interpretation casts humanity into an uncertain void through which forms drift aimlessly, hopelessly, and all individual agency is superseded by the pull of an invisible, irresistible force: certainly not the rational, ordered universe that philosophy promises. Reflecting more closely the sentiments felt during the finde-siècle period, as opposed to classical philosophical thinking, Gottfried Fliedl suggests that the "social impotence of the liberal middle classes was seen as embedded in a relentlessly regular cycle of nature in which the individual was relieved of the necessity to act, while at the same time becoming an observer of himself and the mysterious happenings of the world." 4 Moreover, as it pertains to the question at hand, Klimt manages to effect the dissolution of certain characteristics that one might define as Apollonian, notably the illusion of reality that art, at least up to this point, had desperately tried to maintain.

But as Nietzsche explains, the "Apollonian consciousness was but a thin veil hiding from him the whole Dionysiac realm." Once Klimt began to tear the fabric of that veil, it was only a matter of time before the entire edifice could be taken down. If Philosophy was the beginning, it was with the third panel—which depicts the discipline of Jurispru-

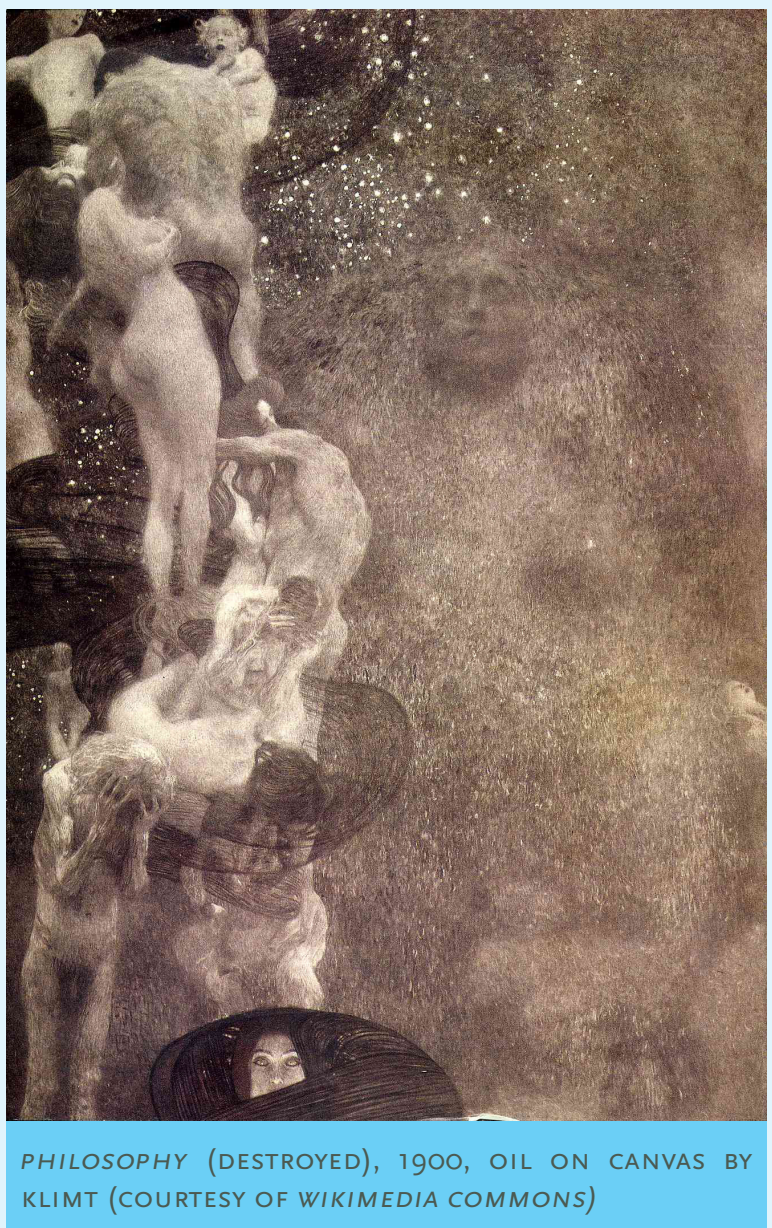




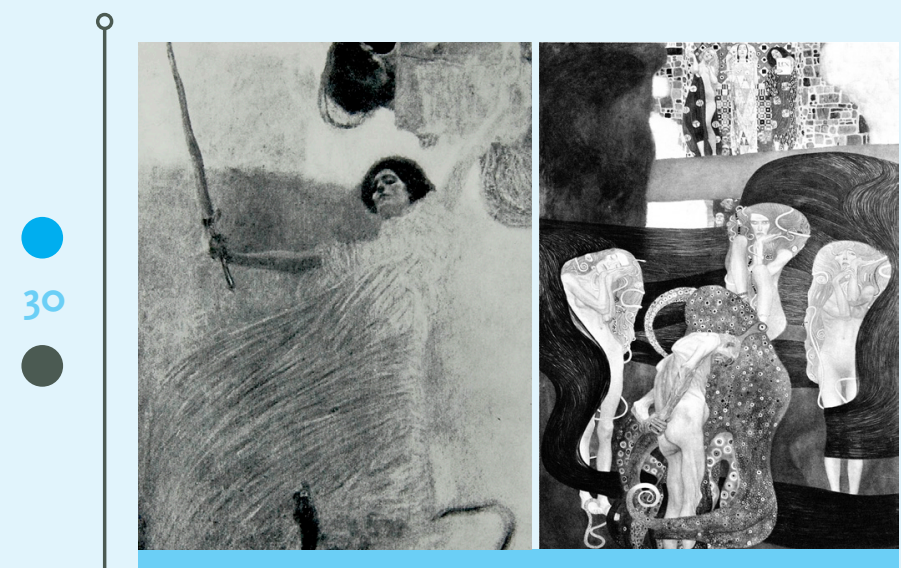

PREPARATORY STUDY FOR JURISPRUDENCE, 1897-98 (LEFT) AND JURISPRUDENCE (DESTROYED), 1903-O7 (RIGHT), BY KLIMT (COURTESY OF FLICKR AND WIKIMEDIA COMMONS)

dence- that we may observe most clearly the descent into the freeing madness that is the Dionysiac form. The final panel itself was born out of a whirlwind of intensely negative emotion; Klimt, after having presented both Philosophy and the second panel, Medicine, to the faculty of the University, was met with open hostility from as high up as the Austrian parliament. A copy of Ver Sacrum in which a preliminary sketch of Medicine had been published was confiscated, and Klimt was left reeling. The preliminary sketch of Jurisprudence is markedly different from that which was eventually delivered; the composition (noticeably the only of the three that would have taken into consideration the paintings' eventual home as ceiling decoration, the subject having been depicted di sotto in sù-as if seen from a lower vantage point) describes an airy, bright world in which the sole figure of Justice wields a sword with which she fulfills her role as arbiter of right and wrong. But through the anger and hurt brought about by the debacle surrounding the other panels, Jurisprudence underwent a transformation. The airy heaven of the first version is gone and in its place is a claustrophobic hellscape in which the University's ideas of "truth and justice" have been redefined as "crime and punishment."

Jurisprudence represents a marked shift in Klimt's manner of depiction, as the figures of Truth, Justice, and Law, far removed from the main action of the foreground, are all cloaked in some of the first instances of the flattened, geometric patterns that would come to dominate and define the artist's mature style. Aside from this, the work is also worth noting as it coincides with an increased tendency towards a more personally relevant, psycho-sexual content. Schorske has proposed, rather convincingly, an argument for associating the nude, male figure of the final University panel with Klimt himself, acting as something of an apologetic self-portrait, a cri de coeur. Sigmund Freud would likely have read phallic symbols into the octopuslike creature consuming the male figure, its tentacles standing in for the male genitals. The actual subject's genitals are obscured by his arrangement, turned away from the viewer. But, presumably, he has been castrated. That the subject's metaphorical castration was enacted by the female Furies is perhaps indicative of the role that female sexuality and its negative reception by the conservative Viennese population played in Klimt's internal crises. According to Schorske, "the iconography suggests that Klimt, under the lash of criticism, even while he fought back, partially internalized as personal guilt the rejection of his artistic mission to act as liberator of the instinctual life from the culture of law. His very defiance was tinctured by the spirit of impotence." ${ }^{6}$ His transgressions were, at base, against his artistic and cultural "forefathers," and by that token, suggestive of an Oedipal rebellion - the punishment of which is, according to Freudian psychoanalysis, castration.

Surely Schorske's suggestion is grounded in some factual evidence. The combination of the figures' blatant sexuality, the aesthetic presentation and stylization of form, and the psychoanalytical subtext of the era which absolutely colored the art produced therein all contributed to what might be considered a 'questionable' work. But could this serve as a complete explanation for the intensely negative reaction? Returning to Nietzsche and the tension between the Apollonian and Dionysiac, we may begin to approach a more comprehensive answer, one that accepts all of these disparate causes and holistically binds them. The Greeks, whose culture gave birth to the myths of both Apollo and Dionysus, "were keenly aware of the terrors and horrors of existence; in order to be able to live at all they had to place before them the shining fantasy of the Olympians." In much the same way, it may be suggested that the Austrian Habsburg Empire, in order to hold together its disparate cultures and people, had no choice but to cling desperately to the order that reason and science promised. Therefore, Klimt's University panels, which effectively dismissed this view as trivial and outdated, were violently rejected. In positioning the Nietzschean and Schopenhauerian pessimistic worldviews as the new norm, Klimt was attacking not only the aesthetic and moral sensibilities of Austria, but also their entire conception of reality. 
If Klimt's work leading up to the University Panels was merely a first foray into the dark and primal pleasure of the Dionysiac, what then might serve as the fullest expression of the concept? To answer that, it is necessary to look to the Vienna Secession and what has become easily their most widely-regarded and well known exhibition: the fourteenth, which celebrated the art of music through the titanic figure of Beethoven. The German artist Max Klinger had very recently completed a monumental, polychrome sculpture of the composer and, "intent on being the first venue for the statue's display, the Secession approached Klinger and proposed to venerate his masterpiece with a new, avant-garde style of exhibition..." 8 Their proposal made use of the unique opportunity afforded them by the Secession building; called "Tempelkunst," they offered to feature Klinger's Beethoven in a space specially constructed so as to highlight the piece, paying homage both to the artist and Klinger himself-all the while highlighting, of course, the art of the Secessionists. ${ }^{9}$ It is my suggestion that Klimt's contribution to the fourteenth exhibition, the infamous Beethoven Frieze more so than nearly any of Klimt's prior or later works, is one that provides an absolutely critical key to understanding the psycho-sexual crisis that contributed to the artist's radical shift in style.

Occupying the upper half of three walls in the the leftmost hall of the Secession building, the Beethoven Frieze was an impressive sight to behold. The entire work was conceived of as a visual interpretation of Beethoven's Ninth Symphony which, in turn, references Schiller's "Ode to Joy," particularly its chorus: "Seid umschlungen Millionen!/ Diesen Kuß der ganzen Welt!/ Brüder-überm Sternenzelt/Muß ein lieber Vater wohnen [Be embrac'd, ye millions yonder!/ Take this kiss throughout the world!/ Brothers-o'er the stars unfurl'd/ Must reside a loving Father.]" ${ }^{\text {ㅇ }}$ Ernst Stöhr, a painter and lesser-known Secession artist, evidently helped Klimt devise the program of the Beethoven Frieze-and he almost certainly wrote the foreword to the exhibition's pro-

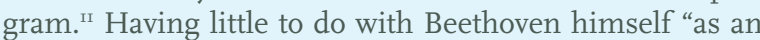
historic figure or spiritual leader," ${ }^{22}$ Stöhr's description of the Beethoven Frieze's content from the exhibition program presents a fin-de-siècle interpretation of the composition of the Ninth Symphony and reads as follows:

The three painted walls constitute a coherent sequence. First long wall across from the entrance: the Longing for Happiness. The Sufferings of weak Humanity: their pleas to the powerful knight in armor as external, to pity and ambition as internal, driving forces which move him to take up the struggle for happiness. Narrow wall: the Hostile Powers. The giant Typhon, against whom even the gods fought in vain; his daughters, the three Gorgons. Disease, insanity and death. Debauchery and unchastity, intemperance [alternately "Lewdness, Lust and Excess"]. Gnawing worry. The longings and desires of humankind fly away over these. Second long wall: the longing for happiness finds appeasement in poetry. The arts lead across into the ideal kingdom where alone we can find pure joy, pure happiness, pure love. Choir of Angels in paradise. "Freude, schöner Götterfunke [sic]. Diesen Kuss der ganzen Welt!" ${ }^{1_{3}}$

Based solely on the textual description, we are presented with a narrative that outlines a journey of salvation, external (i.e. for an "other") but also intensely personal and internal. The Hostile Powers described are, aside from Typhon, all internal plagues to both the physical and psychological states of mankind. Visually, the content of the frieze echoes this second, internal, interpretation favoring a psychoanalytical reading of the piece; after all, when confronted with the nightmarish hellscape of the middle panel "inhabited by bestial monsters and deranged, erotic women," ${ }^{14}$ one cannot help but think of Freud and his Interpretation of Dreams, originally published just two years earlier in I900. Compared to Jurisprudence, which as Schorske reminds us, "was Klimt's boldest expression of narcissistic rage," the Beethoven Frieze was its opposite in nearly every way: "a manifestation of narcissistic regression and utopian bliss. Fight here, found its analogue in flight. Where politics had brought defeat and suffering, art provided escape and comfort. In style as in idea, the Beethoven Frieze marked a turning point in Klimt's art." ${ }^{15}$

\section{"Klimt would begin to break down those very illusions that sustained the Viennese conception of reality and allow the sentiment of the Dionysiac...to seep into and diffuse throughout the work of the modern period."}


As discussed in the context of his University Panels, much of the negative criticism Klimt received was directly linked to the content of his paintings, or in other words, to the blatant sexuality expressed by his female figures. Sexuality, particularly the new sexuality of the modern woman, is key to understanding the frieze. Representations of women in turn-of-the-century art across many cultures were often notably problematic and splintered in regards to the emotional valence of the artists' treatment of subject. Fliedl relates that, during the turn of the century, "there were four linguistic conventions" to express the various aspects of "female identity, which [had become] split up and disintegrated... Weib (a term of contempt), Dame ('lady'), Hure ('whore'), and Mutter ('mother'), words which reflected the social roles of women as well as the wishful thinking and anxieties of men." ${ }^{\text {16 }}$ Nearly all of these are present in Klimt's frieze. Between the images of chastity and virtue in the side panels and the ominous threat of the Hostile Powers in the central panel, the frieze gives voice to a crisis of the artist's ego; it can be very easily argued that Klimt almost surely experienced a similar, internal division.

The full weight of Klimt's psychological presence can be most tangibly felt in his female subjects. He is, according to Marian Bisanz-Prakkan, "always latently present as observer or director; he is the invisible, stable male antithesis to the volatile female psychological state." ${ }^{\text {"77 }}$ As his models appear almost always in varying stages of "reverie or erotic ecstasy," 18 we must necessarily assume that these states of sexual intensity were of particular import to Klimt in painting the Beethoven Frieze and perhaps reveal something of the internal turmoil that marked the man. For example, the placement of the three figures of Lewdness, Lust and Excess centrally on the wall that would have been initially viewed by anyone entering the hall speaks to their corresponding centrality in any reading of the frieze. These women feature as the powers against which the knight, perhaps an avatar for Klimt himself, must struggle for the hope of eventual salvation. But this struggle is not physical; it is the moral struggle of the liberal male ego, confronted with the "ugly, repulsive and aggressive" ${ }^{\text {I9 }}$ sexuality of the female. This may be linked to a very real fear of syphilis (important as it is a sexually transmitted infection, and thus inextricably connected with women) and of which it is said that Klimt was "morbidly afraid." ${ }^{2 \circ}$ But as so much of the interpretation of the frieze lies in the realm of the psychological, and because "each variant of this aggressive side of female nature is derived from anxiety fantasies," ${ }^{21}$ it seems more appropriate to link the fear to their threat against the construct of 'maleness' itself.
In our discussion of Freud's psychoanalysis, we have almost lost sight of Nietzsche's philosophy. Nietzsche actually references Schiller's and Beethoven's "Ode to Joy" by name in direct allusion to the realm of the Dionysiac:

If one were to convert Beethoven's "Paean [Ode] to Joy" into a painting, and refuse to curb the imagination when that multitude prostrates itself reverently in the dust, one might form some apprehension of Dionysiac ritual. Now the slave emerges as a freeman; all the rigid, hostile walls which either necessity or despotism has erected between men are shattered. Now that the gospel of universal harmony is sounded, each individual becomes not only reconciled to his fellow but actually at one with him... ${ }^{22}$

Here, finally, we come to the truth that has up until now only been hesitantly felt in our observation of Klimt's Beethoven Frieze; regardless of its subjectivity-in fact, perhaps even as a result of it-the particular visual content of the frieze and its origins in the music of Beethoven, a veritable hero of art to Klimt's contemporaries, come together to express an otherwise inexplicable condition of humanity. That condition, which I believe that Nietzsche would corroborate, given the research that has been produced in the subject since his death, is the human subconscious, a realm every bit as awesome and terrifying as the philosopher's Dionysiac, perhaps even a substitute definition for the same concept.

Later in 1902, the Secession held their eighteenth exhibition, a Klimt retrospective. The last panel of the Beethoven Frieze - the so-called Kuß der ganzen Welt, the "kiss for the

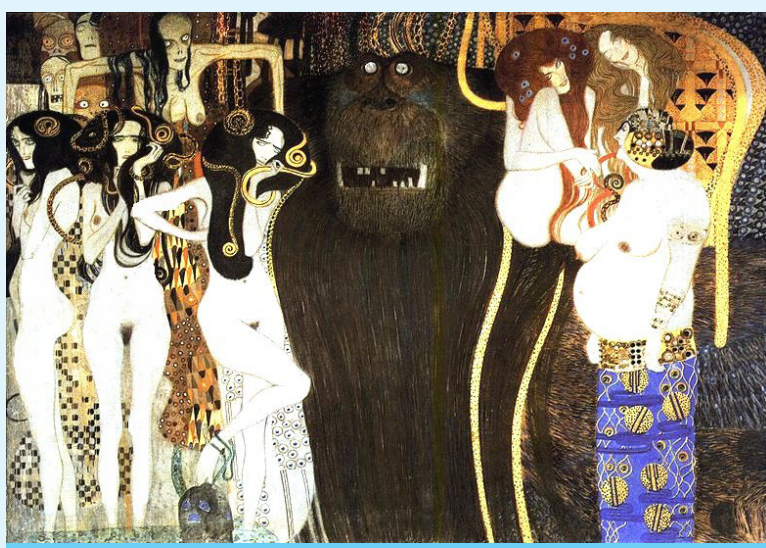

BEETHOVEN FRIEZE ("THE HOSTILE POWERS"), 1902 BY KLIMT (COURTESY OF FLICKR) 


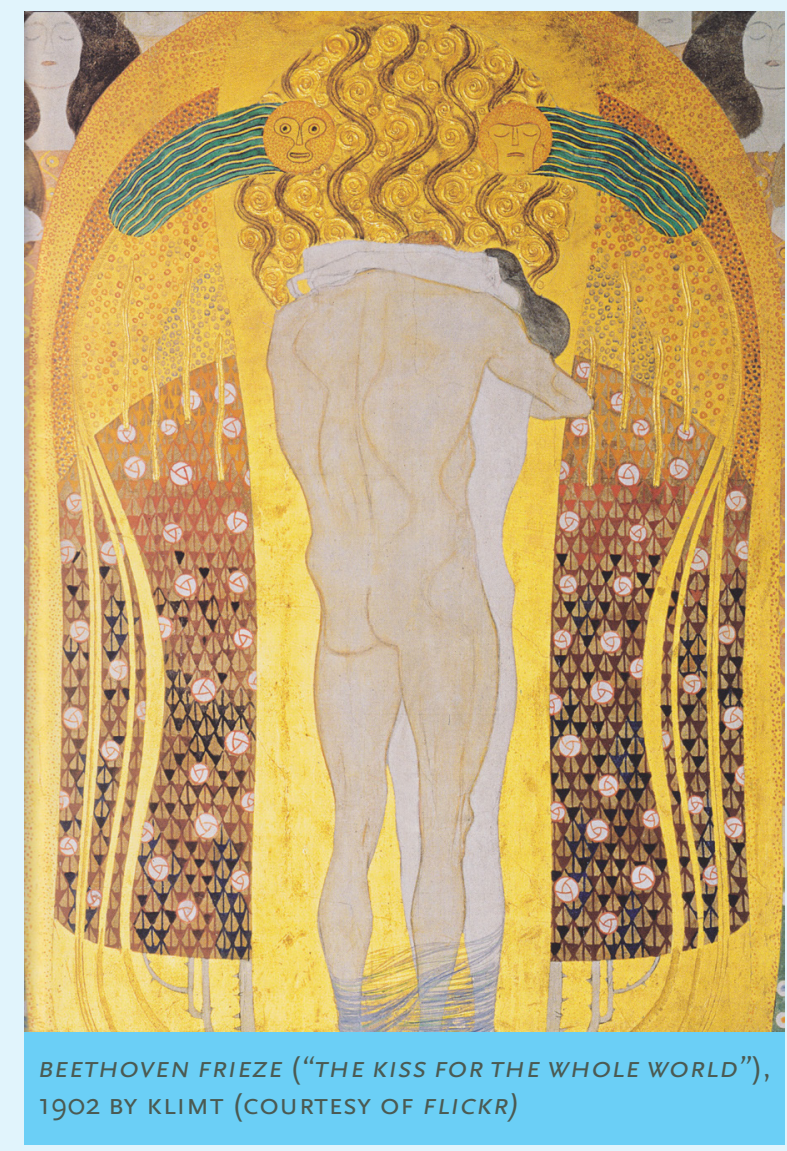

whole world" —was displayed under the title, "Mein Reich ist nicht von dieser Erde." Though initially a reference to John I8:36, "Jesus answered, My kingdom is not of this world: if my kingdom were of this world, then would my servants fight, that I should not be delivered to the Jews: but now is my kingdom not from hence," it is altogether more likely that Klimt appropriated this title from the writings of Richard Wagner. Wagner had, in an essay from I870, used a variation of the quote to comment on Beethoven's music, which he saw as emerging from the chaos of modern civilization: "Both proclaim to us: 'our kingdom is not of this world'. That is to say: we come from within, you from without; we derive from being, you from the appearance of things." ${ }^{23}$ This sentiment defines, perhaps more clearly than anything else, precisely the same principles submitted by Nietzsche in the dichotomous relationship between the Apollonian (i.e. fin-de-siècle Austria:ordered, concerned solely with the illusion of things) and the Dionysiac (i.e. the Secession: burgeoning modernism, the chaotic underpinnings of existence). Through Wagner's comment, we can trace a clear path of thought from Beethoven all the way to Klimt, one that more satisfactorily explains the content of the frieze. Perhaps the Beethoven Frieze was not, as in Klinger's sculpture, a monument to Beethoven himself. Perhaps it was instead a monument to philosophy, to giving oneself over to those forces-most perfectly conveyed through the art of Dionysus' music - that have the potential to bind disparate peoples together in a time of uncertainty, when humanity needed to navigate the collective existential crisis posed by the modern world.

\section{ENDNOTES}

I. Carl E. Schorske, Fin-de-Siècle Vienna: Politics and Culture (New York: Vintage Books, I98I) 2I5.

2. Ibid., 2I\%.

3. Ibid., 226.

4. Gottfried Fliedl, Gustav Klimt: The World in Female Form (Cologne: Taschen, I997) 78.

5. Friedrich Nietzsche, The Birth of Tragedy and The Genealogy of Morals, (New York: Doubleday, I956) 28.

6. Schorske, Fin-de-Siècle Vienna, 252.

7. Nietzsche, The Birth of Tragedy, 29-30.

8. Anna Harwell Celenza, "Music and the Vienna Secession: I897- I902," in Music in Art, Vol. 29, No. I/2, Music in Art: Iconography as a Source for Music History Volume I (SpringFall 2004), 207-208

9. Ibid., 208.

Io. Friedrich Schiller, "An die Freude/Ode to Joy," trans. by William F. Wertz, http://www.schillerinstitute.org/transl/ schiller_poem/ode_to_joy.pdf

II. Celenza, "Music and the Vienna Secession: I897 - I902," 208

I2. Ibid., 209

I3. Ibid., 209

I4. Ibid., 200

I5. Schorske, Fin-de-Siècle Vienna, 254

I6. Fliedl, Gustav Klimt: The World in Female Form, ro8.

I7. Marian Bisanz-Prakkan, "On the Drawings of Gustav Klimt," in Gustav Klimt: In Search of the "Total Artwork," ed. Jane Kallir, co-edited by Alfred Weidinger (Munich: Prestel, 2009), 48.

I8. Ibid., 48 .

I9. Fliedl, Gustav Klimt: The World in Female Form, Io6. 20. Jean-Paul Bouillon, Klimt: Beethoven: The Frieze for the Ninth Symphony (Geneva: Editions d'Art Albert Skira S.A., I987), 73.

2I. Fliedl, Gustav Klimt: The World in Female Form, 106 - 107.

22. Nietzsche, The Birth of Tragedy, 23.

23. Richard Wagner, "Richard Wagner's Beethoven (German text and English translation)," in Richard Wagner's Beethoven (1870): A New Translation (Suffolk: Boydell \& Brewer, 20I4), I79. 


\section{REFERENCES}

Adams, Laurie Schneider. Art and Psychoanalysis. Boulder: Westview Press, I994. DOI: IO.I093/ OBO/9780199920105-0030.

Bisanz-Prakken, Marian. "On the Drawings of Gustav Klimt." In Gustav Klimt: In Search of the "Total Artwork," edited by Jane Kallir, co-edited by Alfred Weidinger, 43 49. Munich: Prestel, 2009. DOI: Io.II63/22I45966. 90000493 .

Bouillon, Jean-Paul. Klimt: Beethoven: The Frieze for the Ninth Symphony. Geneva: Editions d'Art Albert Skira S.A., I987.

Celenza, Anna Harwell. "Music and the Vienna Secession: I897 - I902." Music in Art, Vol. 29, No. I/2, Music in Art: Iconography as a Source for Music History Volume I (Spring-Fall 2004): pp. 203-2I2. http://www.jstor.org/ stable/4I8I8762. DOI: I0.I525/jams.2009.62.3.647

Fliedl, Gottfried. Gustav Klimt: The World in Female Form. Cologne: Taschen, I997.

Kallir, Jane. "In Search of the 'Total Artwork': Klimt, the Secession and the Wiener Werkstätte." In Gustav Klimt: In Search of the "Total Artwork," edited by Jane Kallir, co-edited by Alfred Weidinger, 2I -29. Munich: Prestel, 2009.

Karnes, Kevin C. "Wagner, Klimt, and the Metaphysics of Creativity in fin-de-siècle Vienna." Journal of the American Musicological Society, Vol. 62, No. 3 (Fall 2009): pp. 647$697 . h$ ttp: / / www.jstor.org/stable/IO.I 525 / jams.2009.62.3.647. DOI: Io.1525/jams.2009.62.3.647.

Nietzsche, Friedrich. The Birth of Tragedy and the Genealogy of Morals. New York: Doubleday, I956.

Pollock, Griselda (editor). Psychoanalysis and the Image: Transdisciplinary Perspectives. Oxford: Blackwell Publishing Ltd., 2006.

Schorske, Carl E. Fin-de-Siècle Vienna: Politics and Culture. New York: Vintage Books, I98I.
Terada, Rei. "Strange Intelligibility: Clarity and Vivacity in Dream Language." In The Dreams of Interpretation, edited by Catherine Liu, John Mowitt, Thomas Pepper, and Jakki Spicer. Minneapolis: University of Minnesota Press, 2007. http://www.jstor.org/stable/ro.5749/j.ctttt3ph.2I.

Varnedoe, Kirk. Vienna 1900: Art, Architecture Q Design. New York: The Museum of Modern Art, I986.

Wagner, Richard. "Richard Wagner's Beethoven (German text and English translation)." In Richard Wagner's Beethoven (1870): A New Translation. Suffolk: Boydell \& Brewer, 20I4: 29 - I99. http://www.jstor.org/ stable/10.7722/j.ctt6wp854.7.

Walker, John A. "Dream-Work and Art-Work." Leonardo, Vol. I6, No. 2 (Spring, I983): pp. I09-II4. http://www.jstor.org/stable/I574795. DOI: I0.2307/I574795. 